\title{
Corporate Governance and Global Communication
}

\author{
Giuseppina Gandini*
}

\begin{abstract}
Communication plays a decisive role to evaluate how corporate responsibilities are taken and to recognise the potential to meet the expectations of the various social interlocutors.

Information about the system of corporate governance, in terms of structural and operating characteristics, allows the user to assess its suitability, particularly in the light of the growing corporate complexity and the increasingly risky challenges of globalisation.

Legislative intervention and self-regulation, at a national and international level, is oriented primarily to encouraging transparency, in the face of behaviour that is not always sufficiently correct.
\end{abstract}

Keywords: Corporate Governance; Economic-Financial Communication; Global Communication; Models of Corporate Governance; Comparative Analysis of Corporate Governance

\section{Introduction}

The growing significance that corporate communication is acquiring in modern market economies can be attributed not only to the increased openness and permeability to information of the various stakeholders but also the absolute need to re-establish relationships of trust and consensus to combat behaviour that is ambiguous and at times even improper.

The steady increase in the complexity of corporate systems, the globalisation of the markets and attitudes that do always reflect ethical behaviour, are all elements that enforce the need to re-establish an overview that can underline the importance of relations between the company and its many stakeholders.

Communication plays a decisive role to evaluate how corporate responsibilities are taken and to recognise the potential to meet the expectations of the various social interlocutors.

* Full Professor of Business Administration, University of Brescia (giuseppina.gandini@eco.unibs .it)

Edited by: ISTEI - University of Milan-Bicocca

ISSN: 1593-0319

Gandini Giuseppina, Corporate Governance and Global Communication, Symphonya. Emerging Issues in Management (symphonya.unimib.it), n. 1, 2006, pp. 62-78

http://dx.doi.org/10.4468/2006.1.05gandini 
The acquisition of consensus and resources, even at an international level, around the corporate mission and strategies therefore determines a growing need for clear answers to the various expectations of knowledge expressed inside and outside the company. It also underlines the need to verify the rationalisation and consistency of the messages, guaranteeing their effectiveness, transparency and convergence for the success of the company.

Information about the system of corporate governance, in terms of structural and operating characteristics, allows the user to assess its suitability, particularly in the light of the growing corporate complexity and the increasingly risky challenges of globalisation. Transparency about the composition and degree of independence of the administrative governance organs, about the control functions and relations between administrative and control functions, about the strategic orientation pursued and corporate decisions taken, particularly with regard to the market, about stock market performance, and about the results that the company has achieved and intends to pursue, provides users with information that helps them in their own evaluation processes and, therefore, to consciously establish better economic relations with the company.

Legislative intervention and self-regulation, at a national and international level, is oriented primarily to encouraging transparency, in the face of behaviour that is not always sufficiently correct.

In view of the above, this analysis regards an evaluation of the consistency between conceptual approach, current legislation and governance communication, and aims to analyse and evaluate the qualitative and quantitative aspects of the governance relationship, and to understand the effectiveness of corporate communications in order to qualify relations with stakeholders even from different countries.

\section{Influence of Legislation Regulating Companies' Governance Responsibility}

The need to harmonise the legislation that regulates the corporate governance of companies from different countries, forces analysts to focus first of all on a detailed analysis of the responsibilities attributed to governance organs.

From a structural viewpoint, corporate governance is correlated to the organs responsible for providing it and is expressed in terms of management and supervisory activities. The composition of the organs and the attribution of roles, and of administrative and supervisory tasks, are the basic conditions for correct functioning.

The purpose of generally accepted and shared standards and principles is to indicate the number of the organs, the minimal size, the related responsibilities and tasks and the forms of interaction.

The number and composition of governance organs is decided by:

- legislation and customs in each country;

- current codes of corporate law;

- the characteristics of the institutional structure;

- the constraints and/or conditions imposed by external supervisory organisms;

- the choice of opportunities and composition of the governance organ. 
The principles that underpin current legal systems divide countries into so-called Common law countries on one hand, and Civil law countries on the other. The former are primarily 'Anglo-Saxon' countries like the United Kingdom and the United States of America (but also Australia and Canada), which adopt a Common Law system based on unwritten laws and previous legal judgements and decisions. The latter, primarily European, adopt a Civil Law system that is based on Roman law, legal codes and doctrines, which act as a guide and limitation for corporate activities.

In recent years, tenets of company law that regulate the characteristics of a company's corporate structure have attributed particular importance to joint-stock companies and the specific features of their shareholder base: concentrated ownership (Insider System), a phenomenon typical of European countries; or extremely fragmented ownership (Outsider System), a situation typical of 'AngloSaxon' countries. In the first case we find joint-stock companies with a clearly identified majority shareholder (or a group of related shareholders), in which the relationship with the government, banks and investors takes on particular significance, and a governance system in which the powers of administration and management are quite often clearly separated from those of supervision (Two-tier System). In the second case, we have the so-called public companies, in which the market acts as a regulator of ownership, controlling the activities of the shareholders and managers, through changes in the shareholder base, and the governance system groups together the functions of administration, management and control (One-tier System).

Where governance structures and the separation of administrative and supervision functions are concerned, we usually refer to One-tier and Two-tier systems. The latter, in turn, can be divided into: vertical two-tier, in which the Shareholders appoint the supervisory organ, which, in turn, appoints the administrative organ; horizontal two-tier (described as traditional or ordinary in Italy), in which the Shareholders appoint both the administrative organ and the supervisory organ (Table 1).

Table 1: Models of Corporate Governance

\begin{tabular}{l|c|c|c}
\hline \multirow{2}{*}{ Administration } & \multicolumn{2}{|c|}{ TWO-TIER SYSTEM } & \multirow{2}{*}{ ONE-TIER SYSTEM } \\
\cline { 2 - 3 } & $\begin{array}{c}\text { Hole Director or BoD } \\
\text { appointed by } \\
\text { Shareholders }\end{array}$ & $\begin{array}{c}\text { Management Board } \\
\text { appointed by Supervisory } \\
\text { Board }\end{array}$ & $\begin{array}{c}\text { Board of Directors } \\
\text { appointed by Shareholders }\end{array}$ \\
\begin{tabular}{l|c|c} 
Supervision \\
administration)
\end{tabular} & $\begin{array}{c}\text { Board of Auditors } \\
\text { appointed by } \\
\text { Shareholders }\end{array}$ & $\begin{array}{c}\text { Supervisory Board } \\
\text { appointed by Shareholders }\end{array}$ & $\begin{array}{c}\text { Management control } \\
\text { committee appointed by } \\
\text { BoD }\end{array}$ \\
\hline Accounting control & $\begin{array}{c}\text { External auditor } \\
\text { (or auditing company) } \\
\text { member of Register of } \\
\text { auditors, appointed by } \\
\text { Shareholders }\end{array}$ & $\begin{array}{c}\text { External auditor } \\
\text { (or auditing company) } \\
\text { member of Register of } \\
\text { auditors, appointed by } \\
\text { Supervisory Board }\end{array}$ & $\begin{array}{c}\text { External auditor } \\
\text { member of Register of } \\
\text { auditors, appointed by } \\
\text { Shareholders }\end{array}$ \\
\hline
\end{tabular}


The traditional (or horizontal two-tier) model has features in common with both the other models and is particularly widespread in Italy. This is due to the fact that in the past, a strongly state-based economy limited the development of widespread capitalism and prompted the adoption of a mixed system of governance although today, following recent legislative changes ${ }^{1}$, it is possible to choose between a onetier system and a two-tier system. (Table 2 ).

Table 2: National Legal Systems and Governance Systems

\begin{tabular}{|c|c|c|c|c|c|c|c|}
\hline \multirow{3}{*}{$\begin{array}{c}\text { Corporate } \\
\text { Governance }\end{array}$} & \multicolumn{2}{|c|}{ Common Law countries } & \multicolumn{5}{|c|}{ Civil Law countries } \\
\hline & \multirow{2}{*}{$\begin{array}{l}\text { UNITED } \\
\text { STATES OF } \\
\text { AMERICA }\end{array}$} & \multirow{2}{*}{$\begin{array}{c}\text { UNITED } \\
\text { KINGDOM }\end{array}$} & \multicolumn{5}{|c|}{ EUROPE } \\
\hline & & & Germany & France & Italy & Spain & Russia \\
\hline $\begin{array}{c}\text { Traditional or } \\
\text { horizontal two-tier } \\
\text { system }\end{array}$ & & & & & $\mathrm{X}$ & & $\mathrm{X}$ \\
\hline $\begin{array}{c}\text { Vertical two-tier } \\
\text { system }\end{array}$ & & & $\mathrm{X}$ & $\mathrm{X}$ & $\mathrm{X}$ & & $\mathrm{X}$ \\
\hline One-tier system & $X$ & $X$ & & $\mathrm{X}$ & $X$ & $X$ & $X$ \\
\hline
\end{tabular}

Comparative analysis from the viewpoint of corporate systems in different Western countries divided, on the basis of their national legal systems, into common law countries and civil law countries, highlights a number of differences regarding corporate governance, stock ownership, the capital market and the corporate culture ${ }^{2}$.

Joint-stock enterprises have legal characteristics and related problems that are basically similar ${ }^{3}$ although certain dissimilarities exist regarding these profiles.

First of all, the choice of corporate governance models is correlated, in particular, with the adoption of codes of self-discipline issued at a national level (by organisms connected to Stock Exchanges), or absorbed indirectly even if they originate from professional organisms (banking, insurance, industrial, etc.). At a European level, the most recent measures to consolidate codes of self-discipline which are generally not compulsory, although failure to respect them must be motivated - regarded first France (the Rapport Vienot of 1995) and Spain (Codigo Olivencia of 1998), and then Italy (in 1999, revised in 2002 and again in 2006), Germany and Russia (2002). Common law countries like the UK, with the Cadbury Code of 1992 and then the Combined Code, or the USA, with the indications of important organisms first, and finally with the NYSE Corporate Governance Rules of 2003, reflect the prime importance, albeit not binding, of these codes and the best practices they contain. However, it was considered essential to strengthen these indications with binding codes of practices, contained in the Company Law 
Reform Bill (2006) for the United Kingdom and the benchmark legislation of the Sarbanes-Oxley Act (2002) for the USA.

The presence and acceptance of codes of self-discipline strengthens the image of the governance of a company that operates on the international markets; on the other hand, its legitimation stems from the convergence of the legislative models adopted and from recognition of shared values, first and foremost those of the transparency and truthfulness of corporate communication.

The structure of corporate governance is closely linked to the stock ownership, seen both as the right to control the company and the right to enjoy the profits achieved from the activity performed, and this is reflected in relations with internal and external interlocutors. There can be no doubt that regulating the main conflicts between the various players in the corporate enterprise influences the governance structure and affects relations between shareholders, between managers and shareholders, and between shareholders and other stakeholders who are tied to the company in various ways, particularly employees and creditors ${ }^{4}$.

The exercise of the right of ownership or of control is affected by the existing corporate culture (concentration/diffusion of ownership and direct or indirect control) and tends to influence the capital market by increasing or decreasing its appeal in relation to the composition of the administrative organ, the delegation of management and the means by which control is exerted.

Although it is formally separate from the shareholders, the composition of the administrative organ is influenced by the orientation of the owners (widespread shareholder base outsider system or concentrated shareholder base insider system), whose equity and autonomy in relation to all company interlocutors (majority shareholders, minority shareholders, employees, creditors, suppliers, etc.) becomes easier to guarantee as the number of independent administrators increases.

Delegating management to an administrative organ results in conflict between the vertical two-tier system and the one-tier system:

- the former, which has taken hold in Italy as a result of its implementation in a number of important listed companies (particularly as an effect of certain significant mergers in the banking and insurance sectors, even of an international nature), recognises that by splitting the organs, it is possible to include top managers in the management board which, because it is appointed by but separate from the supervisory board, excludes management from involvement in the latter which in fact represents the owners;

- the latter envisages the possibility of managers being on the board of directors, and because they also play a part in the creation of the supervisory boards, they can become dominant position and generate undue interference in the essential distinction between the adoption of decisions (administrative organ), the execution of decisions (operational management) and supervision of managers' operations and decisions (administrative organ).

The formal separation between the administrative organ and company managers is very important, not only in terms of supervision of the quality of decisions and their implementation, but also of the behaviour of the persons responsible for their implementation, as well as the results achieved and pursued by stakeholders, led by the shareholders. 
The supervision of economic-financial communication, management activities, the appointment/dismissal of governance organs and respect of the laws and of regulations are the responsibility of different organisms depending on the models used (Table 3).

The spread of two-tier models in civil law countries reflects the need to respond on one hand, to limited ownership systems (which are, however, expanding in response to the revitalisation of the stock markets) that intend to play an active and decisive role in the appointment of governance organs; and on the other hand, to the possibility of intervening directly on the control, faced with precise legal requirements for accounting supervision and legality, and of monitoring the suitability of the company's organisational, administrative and accounting set-up ${ }^{5}$.

Table 3: Governance Models and Functions of the Various Governance Organs

\begin{tabular}{|c|c|c|c|c|c|}
\hline & $\begin{array}{l}\text { DRAFTING OF } \\
\text { FINANCIAL } \\
\text { STATEMENTS }\end{array}$ & $\begin{array}{l}\text { APPROVAL OF } \\
\text { FINANCIAL } \\
\text { STATEMENTS }\end{array}$ & $\begin{array}{c}\text { CORPORATE } \\
\text { MANAGEMENT }\end{array}$ & $\begin{array}{c}\text { APPOINTMENT/ } \\
\text { DISMISSAL OF } \\
\text { ADMINISTRATIV } \\
\text { E ORGAN }\end{array}$ & $\begin{array}{c}\text { CONTROL OF } \\
\text { LEGALITY AND } \\
\text { CORRECT } \\
\text { ADMINISTRATI } \\
\text { ON } \\
\end{array}$ \\
\hline $\begin{array}{l}\text { Traditional or } \\
\text { horizontal two- } \\
\text { tier model }\end{array}$ & $\begin{array}{l}\text { Board of } \\
\text { directors }\end{array}$ & Shareholders & $\begin{array}{l}\text { Board of } \\
\text { directors }\end{array}$ & Shareholders & $\begin{array}{l}\text { Board of } \\
\text { auditors }\end{array}$ \\
\hline $\begin{array}{ll}\text { Vertical two- } \\
\text { tier model }\end{array}$ & $\begin{array}{c}\text { Management } \\
\text { board }\end{array}$ & $\begin{array}{c}\text { Supervisory } \\
\text { board }\end{array}$ & $\begin{array}{c}\text { Management } \\
\text { board }\end{array}$ & $\begin{array}{c}\text { Supervisory } \\
\text { board }\end{array}$ & $\begin{array}{c}\text { Supervisory } \\
\text { board }\end{array}$ \\
\hline One-tier model & $\begin{array}{l}\text { Board of } \\
\text { directors }\end{array}$ & Shareholders & $\begin{array}{l}\text { Board of } \\
\text { directors }\end{array}$ & Shareholders & $\begin{array}{c}\text { Internal } \\
\text { Management } \\
\text { control } \\
\text { committee }\end{array}$ \\
\hline
\end{tabular}

The adoption of the one-tier model, originally developed in and typical of common law countries, highlights first of all the will to delegate decision-making powers to the administrative organ which has all the powers and responsibilities, including that of supervision. However, recourse to numerous rules of best practice makes it possible to limit the size of the administrative organ, creating independent and restricted committees that monitor the control system, in particular, but also the system of appointments and salaries ${ }^{6}$.

\section{Corporate Communication in Common Law and Civil Law Systems}

The effectiveness of corporate communication, the use of increasingly sophisticated tools for its dissemination and its repercussions for the company's success have been analysed and studied over the years by numerous experts of corporate economics ${ }^{7}$. However, the multi-faceted observation of complex corporate events correlated to the unpredictable dynamism and discontinuity of events characterising global markets reveals that the importance of adopting a consistent, effective approach to communication, which aims to satisfy all expectations of information with clear, truthful, comprehensive and exhaustive messages, has still not been taken on board. 
We can note: the poor quality of the messages communicated; the formal and substantial deformity of the contents of the information that is often expressed in a limited and/or confused way, spaces and times even by companies operating in the same sector and market; partial and/or reticent disclosure of corporate performances (occasionally with information that is suitably manipulated to meet the issuer's objectives); the conscious omission of significant information. All this underlines the need to assess the depth and space-time conformity of corporate communication in order to strive for uniform conduct that respects the provisions of different legal systems and to guarantee effective, transparent governance.

The success of the company and the probability of maintaining it, are reflected in the capacity to establish communication flows that can satisfy the expectations of information and evaluation of the various stakeholders.

The evident deficiencies in the messages spread by the companies have actually stimulated the intervention of institutions from different sectors (professional associations, national, European and international public bodies) with the common intent of improving relations within the company and with the market.

In recent years, the legal systems of the various countries have issued a structured, sequential set of standards and recommendations for corporate governance communication. In certain countries these provide orientation for the preparation of the corporate governance report; in other countries a list has been drawn up of the principle information necessary to guarantee minimal information, and in others still, no specific recommendations were made to draft an independent report on corporate governance, nor for the inclusion of information related to the annual report.

The comprehensiveness of information, the exhaustiveness of communications, control through data, and transparency about corporate events are still fairly distant goals.

The characteristics and specifics of codes of practice differ between civil law and common law countries, as indicated earlier, and pose difficulties regarding the link between communication and respect of the principle of transparency. This differentiation is particularly evident if we think of the basic logic that underpins each system. As we mentioned, while in civil law countries the rules are written and primarily formalised in codes, constituting a complex legal framework that each party must comply with, in common law countries rules are basically expressed in a vast number of legal precedents, and the general principle establishes that a final judgement acquires the force of law in similar cases (stare decisis ).

The legal system that the issuing company belongs to therefore has a profound influence on corporate communication, creating ample potential to distinguish between companies that operate in civil law countries and those in common law countries or in both.

The disclosure of economic-financial information in civil law countries is mainly regulated by law and limited to principles and criteria whose structural and formal characteristics are described in written codes of practice, and enforced at least to a minimal degree. Communication methods in common law countries, on the other hand, are regulated by widespread and consolidated habits that acquire an implicit value. In fact, these systems are based on a limited number of laws or Acts, which refer to individual cases, subsequently becoming Case Law. Each regulation therefore becomes an analogical precedent for future decisions, contributing to the creation of the body of law. 
From the legal viewpoint described, the subtle distinction between the elements of limitation and discretionality of communication, establishes the minimal amount of information that can be expected of a company, although it does not guarantee reliability and timeliness, creating difficulties of clarity and evaluation.

The representation and content of economic-financial information are contemplated in the various standards that characterise the methods for the disclosure of corporate messages established in each country as a constraint that issuers must respect.

In the majority of European civil law countries, there is a ramified and complex system of standards designed mainly to define:

- periodical publication of documentation and indications of the formal structure and the minimal compulsory content;

- additional information that must be disclosed occasionally if specific events occur;

- $\quad$ rules for the preparation of discretionary communication documents;

- the methods and the parties obliged to respect the publication of specific company events.

However, we must point out that although non-observance of the law undoubtedly reveals an improper and criminally liable attitude, it is not entirely true that, on the contrary, legally correct behaviour does not hide fraudulent intent, In fact, respect of legal obligations is a necessary condition but not sufficient to guarantee socially responsible behaviour or comprehensive, truthful and transparent information. This happens in particular because of numerous limits inherent in the legal system in force, including:

- the ample discretionary space left by the legal system which could legally justify the disclosure of ethically incorrect information;

- the existence of factors of constraint not always able to guarantee the quality of the communication;

- the many contexts that are not expressly regulated even in civil law countries, which are occasionally disciplined by customs and habits that are consolidated but nonetheless often not in line with the development and needs of the environment;

- the rigidity of the standards in relation to the various fields of application (territorial, sectorial, environmental);

- incompatibility between obsolete legal systems and the current need for information about the economic-social-environmental system;

- the difficulty of reconciling timing and bureaucratic procedures related to the means of regulation and/or adaptation to the changes in the economic-socialenvironmental system;

- adaptation to higher provisions (European, national, regional) that do not always respond to the specific needs of smaller organisations.

The situation described reveals that it is still difficult to find common legislative references that make it possible to adopt quality corporate communication models based on universally accepted principles designed to corroborate the assumption of broad responsibility towards all the stakeholders.

In the context outlined, particularly with regard to global companies that operate in countries with different legal systems and have adopted different governance models, 
the existence of a more discretionary and flexible system not based on written and formal standards and codes, but one in which there is a clear reference to generally accepted rules and principles of behaviour, is justified. This phenomenon confirms the principle modelled on freedom of expression, the superiority of moral and ethically shared values, even with respect to legal standards, as a body of criteria that inspire the guidelines adopted in corporate management.

In fact, even if the common law system reveals a minimal basic structure of orientation to corporate communication, the existence of a legal system characterised by the primary role of jurisprudence and the absence of a system of codified law draws attention to the need for greater limitation. On the other hand, it is useful to point out that the effectiveness of communication does not lie exclusively in legal dictates, because it is nonetheless influenced by the will to communicate transparently and comprehensively.

Although there is a fundamental difference in approach between the two systems, recently there has been a substantial alignment between the current body of laws governing corporate communication (Table 4). The United Kingdom - because of its geographical vicinity to civil law countries and also of its membership of the European Union - has a similar orientation to countries that have their own body of regulations governing commercial activities, with more evident areas of overlap than the USA.

Since 1985, in the UK there has been a systematic reorganisation of previous company law with the Companies Act, and this has been followed by a number of legislative changes designed to regulate economic information to protect potential and current investors, regarding specific legal procedures ${ }^{8}$. American legislation of corporate communication is based primarily on federal Securities laws, national accounting principles issued by the Financial Accounting Standards board and Regulations issued by the Securities Exchange Commission.

In both countries, the legal system has established indications regarding significant information to be included in compulsory information about governance results.

In European civil law countries ${ }^{9}$, the main sources of the rules for economicfinancial information are:

- the various codes (commercial in France and Germany, civil in Italy);

- national accounting principles, recommendations, interpretations, announcements and opinions of specific national organisms ${ }^{10}$.

The possibility of developing different forms and means of corporate communication, both compulsory and optional, required by the different legal systems, reflects the distinctive characteristics of the prevalent governance models that differentiate common law countries from civil law countries. An initial examination of the information requested, in particular from the many large companies with a strong brand impact that operate on global markets and respect different legal systems (such as, in the case of the motor industry, listed and global companies like General Motors, Fiat, Toyota, Roll-Royce and Volkswagen), reveals that the essential requirements represented by the obligation to provide financial statements and related documents are respected. Although this represents an appreciable stimulus to the development of uniform basic economic-financial communication, there is still a lack of a better regulated approach to self-discipline and external supervision in common law countries compared to civil law countries. 
Table 4: Comparative Analysis of Economic-Financial Communication and Corporate Governance in the USA, UK and Europe

\begin{tabular}{|c|c|c|c|}
\hline LEGAL SYSTEMS & \multicolumn{2}{|c|}{ COMMON LAW } & CIVIL LAW \\
\hline Type of document & USA & $\begin{array}{c}\text { UNITED } \\
\text { KINGDOM }\end{array}$ & EUROPE \\
\hline \multicolumn{4}{|l|}{$\begin{array}{l}\text { Information about } \\
\text { Corporate } \\
\text { Governance } \\
\end{array}$} \\
\hline $\begin{array}{l}\text { Corporate } \\
\text { governance } \\
\text { document }\end{array}$ & $\begin{array}{l}\text { Sarbanes-Oxley Act } \\
(2002) \\
\text { Final NYSE } \\
\text { corporate } \\
\text { governance rules } \\
(2004-2006)\end{array}$ & $\begin{array}{l}\text { Combined Code } \\
(2003-2005)\end{array}$ & $\begin{array}{l}\text { Italy: guidelines for the } \\
\text { preparation of corporate } \\
\text { governance reports } \\
\text { France: Recommandations sur } \\
\text { le gouvernement d'entreprise } \\
\text { Germany: Deutscher } \\
\text { Corporate governance } \\
\text { (Kodex) } \\
\text { Russia: The Russian corporate } \\
\text { governance roundtable } \\
\text { Spain: Annual report on } \\
\text { corporate governance }\end{array}$ \\
\hline \multicolumn{4}{|l|}{$\begin{array}{l}\text { Compulsory } \\
\text { information about } \\
\text { results of } \\
\text { governance }\end{array}$} \\
\hline $\begin{array}{l}\text { Benchmark code of } \\
\text { practice }\end{array}$ & $\begin{array}{l}\text { Generally Accepted } \\
\text { Accounting } \\
\text { Principles (GAAP) }\end{array}$ & IV EU Directive & IV EU Directive \\
\hline $\begin{array}{l}\text { Statutory financial } \\
\text { statements }\end{array}$ & Compulsory & $\begin{array}{l}\text { Compulsory for all } \\
\text { joint-stock } \\
\text { companies, or } \\
\text { Registered } \\
\text { Companies, that can } \\
\text { take the legal form } \\
\text { of a Public limited } \\
\text { company (Plc) or } \\
\text { Private limited } \\
\text { company (Ltd). }\end{array}$ & Compulsory \\
\hline
\end{tabular}




\begin{tabular}{|c|c|c|c|}
\hline $\begin{array}{l}\text { Structure and } \\
\text { annexes }\end{array}$ & $\begin{array}{l}\text { Balance sheet in } \\
\text { report form, or in } \\
\text { traditional form. } \\
\text { Statement of } \\
\text { operations in report } \\
\text { form with costs } \\
\text { classified by } \\
\text { destination. } \\
\text { Explanatory } \\
\text { schedule of values } \\
\text { entered in summary } \\
\text { tables. Report on } \\
\text { operations. } \\
\text { Financial Statement } \\
\text { of cash flows }\end{array}$ & $\begin{array}{l}\text { Balance sheet, } \\
\text { Statement of } \\
\text { operations adopting } \\
\text { all the schedules } \\
\text { envisaged by EU } \\
\text { legislation. } \\
\text { Explanatory annex, } \\
\text { report on operations, } \\
\text { Statement of source } \\
\text { and application of } \\
\text { funds, Statement of } \\
\text { changes to } \\
\text { Shareholders' } \\
\text { equity, notes on } \\
\text { results achieved on } \\
\text { basis of historical } \\
\text { costs, schedule of all } \\
\text { recognised profits } \\
\text { and losses. }\end{array}$ & $\begin{array}{l}\text { Balance sheet, Statement of } \\
\text { operations and Notes to } \\
\text { financial statements. Report } \\
\text { on operations. } \\
\text { (In some European countries } \\
\text { - France and Germany - law- } \\
\text { makers have given } \\
\text { companies the option of } \\
\text { choosing between the various } \\
\text { schemes contemplated by the } \\
\text { Directive; in others - Italy - } \\
\text { the law is more precise and } \\
\text { limited.) }\end{array}$ \\
\hline $\begin{array}{l}\text { Other compulsory } \\
\text { documents }\end{array}$ & $\begin{array}{l}\text { Auditors' report } \\
\text { (only for companies } \\
\text { subject to SEC } \\
\text { control). } \\
\text { Consolidated } \\
\text { financial statements } \\
\text { (the SEC makes it } \\
\text { compulsory for } \\
\text { subsidiary and } \\
\text { parent companies } \\
\text { that apply to be } \\
\text { listed on the Stock } \\
\text { exchange). Annual, } \\
\text { quarterly report, } \\
\text { episode-based } \\
\text { reports (for listed } \\
\text { companies). }\end{array}$ & $\begin{array}{l}\text { Auditors' report (for } \\
\text { all listed and un- } \\
\text { listed companies } \\
\text { excluding Dormant } \\
\text { Companies); } \\
\text { Consolidated } \\
\text { financial statements } \\
\text { (for companies } \\
\text { exerting control over } \\
\text { other companies); } \\
\text { Half-yearly report, } \\
\text { quarterly report, } \\
\text { schedule illustrating } \\
\text { ownership structure } \\
\text { (for listed } \\
\text { companies). }\end{array}$ & $\begin{array}{l}\text { Auditors' report (in some } \\
\text { countries only for listed } \\
\text { companies, in others also for } \\
\text { medium and large sized } \\
\text { companies). } \\
\text { Consolidated financial } \\
\text { statements (different context } \\
\text { of application). } \\
\text { Interim reports. } \\
\text { Social report (in France for } \\
\text { companies with more than } \\
300 \text { employees). }\end{array}$ \\
\hline $\begin{array}{l}\text { Voluntary } \\
\text { information about } \\
\text { results of } \\
\text { governance }\end{array}$ & $\begin{array}{l}\text { Highlights } \\
\text { Segment data }\end{array}$ & $\begin{array}{l}\text { Highlights } \\
\text { Segment data }\end{array}$ & $\begin{array}{l}\text { Highlights } \\
\text { Reclassified schedules } \\
\text { Financial statement indices } \\
\text { Segment data }\end{array}$ \\
\hline $\begin{array}{l}\text { Voluntary } \\
\text { governance } \\
\text { information }\end{array}$ & $\begin{array}{l}\text { Environmental } \\
\text { report } \\
\text { Social report } \\
\end{array}$ & $\begin{array}{l}\text { Environmental } \\
\text { report } \\
\text { Social report } \\
\end{array}$ & $\begin{array}{l}\text { Environmental report } \\
\text { Social report (Italy and } \\
\text { Germany). }\end{array}$ \\
\hline
\end{tabular}

The polyvalent disclosure to the various stakeholders, ease of access, the updating and reliability of information, particularly via the Internet, must be guaranteed from a formal (corporate governance, investor relations) and a substantial viewpoint (financial statements and listings), by global communication that:

- simplifies the analysis and comparison of the data presented;

- offers guarantees of transparency;

- reaches a wide audience;

- reduces the time necessary to access information and its cost;

- presents a correct, truthful picture of the company; 
- allows detailed analysis of the information that is significant for the various stakeholders even through interactive reports;

- stimulates and improves the voluntary information about governance that helps to clarify the phenomena behind the evolving structural and operational conditions as well as trends/changes in the basic strategies.

\section{Evolution of Governance Communication and Global Markets}

The globalisation of markets and of information has intensified relations between companies that have registered offices in different countries ${ }^{11}$. This makes it necessary to increase the capacity to meet the demand for information from stakeholders in different parts of the globe, with partially differentiated habits and legislative standards. This phenomenon breaks down space barriers, accompanied by the striving for greater uniformity in corporate communication. In particular the following are changing:

- the contents of governance communication, according to a process designed to overlook strict references to the legislative constraints of a country system in favour of the implementation, by virtuous companies, of the necessary assumptions of global effectiveness;

- the channels adopted to transmit information to increasingly vast and geographically disseminated classes of stakeholders, with extensive use of the Internet.

Listed companies from common law countries with a strong brand name share similar characteristics in terms of size in the form of a group and of extension on international markets, particularly in Europe. Their origins are reflected in references to generally accepted recommendations, and codes of self-discipline that refer to ethical values rather than laws or standards, while the governance structure adopts the one-tier model in respect of the principle of autonomy and responsibility primarily belonging to the board of directors and the managers who are part of it. Cultural orientations and the development of governance at a global level, as established by the guidelines for the corporate governance document, are inspired by trust, transparency, truthfulness and consequent consensus on the basis of a virtual pact. This pact overrides nationality and legal systems, assimilates the basic culture of the managers operating in the various countries, includes the ethical-moral values of the individual, and detects the possible performance and/or non-performance of management, but does not admit a failure to take responsibility or the adoption of improper or fraudulent behaviour.

In the operating logic of the governance system based on the one-tier model, it is very important, as the information collected underlines, to focus on the way the internal control system operates, particularly with reference to risk management. As well as refining the management control process ${ }^{12}$, it is important to guarantee the suitability of the internal control systems by effective and constant auditing and risk management activities. In particular, the latter must be accurately structured in terms of the preventive monitoring of current and future risk and of the emergence of dangerous events. As a result, supervision, the creation of special boards, the 
independence and autonomy of the persons responsible for supervision, become factors that qualify governance able to guarantee the effectiveness of the communication.

In the same way, civil law countries should act constructively to reduce legislative and bureaucratic complexity, and to limit the constraints on flexibility that standards impose. In this sense, for example, in Italy, the 2003 reform of company law (Leg. Decree no. 6 of January 17, 2003 - in force from January 1, 2004) offers a choice between different models of governance, contemplating all the alternatives currently available around the world. The purpose of this is to achieve greater flexibility and openness to exploit composite entrepreneurial cultures even in terms of supervision systems, and self-determination that is correct and transparent in relation to third parties.

Since 2004, some Italian companies have changed from a horizontal two-tier system to a vertical one, and a small number have introduced a one-tier system. However, the process is slow, and entails a review of governance and of the corporate codes of practice that regulate it (i.e. the articles of association), and a parallel redefinition of the various processes that determine its effectiveness; and therefore also an analysis of the quality of corporate communication.

The economic dimension of globalisation, a growing number of multinational corporations, competition on the world markets, and listing on the stock exchanges of different countries, forces companies to carefully appraise the network of direct and indirect relations that can influence their evolution and therefore their strategic positioning. There can be no doubt that real-time information and increasingly advanced IT communication are the ideal media to establish a network of relations that will be more effective the better the information is selected and the more consistent the communication inside the company, from the inside to the outside and vice versa. In order for information and communication to be appreciable tools, it is necessary to encourage the effective integration between the two ${ }^{13}$, particularly at a corporate level to make explicit the composition of relations between the various organs, the decisions and methods for the implementation processes, responsibility and supervisory activities.

The previous analysis made it possible to observe relatively consolidated relations/actions in the case of global companies that operate with the same governance model, although there may be problems in the case of:

- companies operating within a multinational group with different governance models;

- companies that operate in the form of a group with the same governance model in countries with a different system (for example, Walt Disney, a onetier company that operates in Europe);

- companies that acquire different governance models as an effect of international acquisitions/mergers and comply with different systems.

The problems that emerge regarding the need for better communication at an integrated level are also aggravated by the need to guarantee suitable forms of internal and external control.

The combination that links global companies to countries with different systems and to composite governance models, highlights the different expression/composition of 
governance communication linked in particular to the ownership structure, the management and the supervisory organs. We must also highlight the specific nature of relations between the different organs (and therefore the information transmitted by reports), which must be clarified to guarantee healthy and prudent management in relation to all stakeholders. This appears evident where a company with a one-tier system, established in a common law country, merges with a two-tier company operating in a civil law country as part of the process of globalisation: if both models are maintained, the legal guarantees provided by the civil law country must be compensated by equal guarantees of a discretionary rather than an objective nature, and above all the supervisory structures and methods must be negotiated.

Where a homogeneous company emerges ${ }^{14}$, in other words a successful business formula, regardless of the country of origin, the composition of the group, the location of the registered offices, the definition of the holding company and the leadership, this demands homogeneous and integrated corporate communication in order to respond in an exhaustive, differentiated way to the expectations of social interlocutors from different cultures, sectors and markets.

\section{Governance Synergies and Empathy between Global Corporate Cultures}

The adoption of governance models shared by companies or groups of companies that operate on international markets simplifies communication and therefore knowledge, reduces costs and results in shared values and cultural growth.

Corporate effectiveness depends on the structural (equity, transparency, independence and accountability) and operating requirements of governance, on decisions taken by governance organs, and on the means of activation of suitable development process, but also on the definition of suitable forms of control. The adoption of compatible, interactive governance models makes it possible, on one hand, to achieve and step up the integration of communication, and on the other, to take steps to homogenise corporate culture and overcome problems linked to different systems and habits ${ }^{15}$.

The presence of global companies operating as a group in countries with different systems can generate governance synergies in the form of a network, when the companies in the group are able to exercise a more powerful action on the same implementing organ, making it possible:

- to share governance strategies and policies that may differ widely;

- $\quad$ to adopt and respect EU legislative principles and regulations;

- to integrate the internal control system and the implementation of similar communication and control methodologies.

The traditional conception that sets the civil law system against the common law system can be overcome by encouraging the empathy between the culture of global companies, i.e. assuming both the basic principles that underpin the common law system - guided by the ethical values of the individual and the free initiative of the market - and behaviour based on the certainty of shared laws and standards that underpins the civil law system. 
The adoption of numerous codes of self-discipline in common law countries, paying particular attention to the definition of generally accepted criteria for best practice has made it possible to define corporate responsibility in terms of:

- requirements for the transparency and truthfulness of economic communication;

- the creation and expansion of the system of controls on governance (basically compulsory internal committees like the Audit Committee, Nomination Committee and Remuneration Committee, as well as voluntary committees such as the CSR Committee and Ethics Committee);

- safeguarding the independence of internal and external controllers.

The aforesaid guidelines for the definition of a global dimension of accountability in corporate governance are associated with the development of strategies to link stock markets in Europe and worldwide ${ }^{16}$. In order to protect a widespread, active and efficient stock market and all this entails, there has been a strong striving to achieve integrated systems in the monetary field (European Monetary Union is one example), in technology (the Internet and telecommunications) and in legislation (directives regarding the functioning of financial markets and governance).

Listing on the various Stock Exchanges, for example in the USA and the UK, of companies subject to legislation in their home country, for example with a civil law system, entails certain effects based on the governance model adopted and the existing system of checks. In particular, certain rules envisaged by the stock market in question or the watchdog must be respected. These might include an indication of the presence of an audit committee, the principal differences between the governance model adopted and the one envisaged in the country in question, and possible violations of applicable standards.

If integration/alliances between the world's stock markets can make it possible to overcome some barriers and to reduce changes in terms of governance organs, we must also hope to achieve the same integration between companies' control systems. The existence of different legislative systems in different countries must encourage similar control systems for global companies in order to avoid/protect generally from the internationalisation of fraud that can be at least limited by:

- common governance regulations;

- extended, shared corporate culture;

- composition of the economic and social interests of all the parties involved;

- the speed and transparency of information and spread of knowledge.

The strategic orientation of companies operating on global markets must include the striving to achieve conditions that can combine the homogeneous, specific nature of a company with shared common legislative bases and uniform methods of economic governance, in order to create governance synergies, particularly where the supervisory culture is concerned. 


\section{Notes}

${ }^{1}$ For Italy, the Vietti Law (Leg. Decree 6/2003 enforced in January 2004), for the United Kingdom the "Company Law Reform Bill" and Combined Code were approved in July 2006, for the USA, corporate governance was reformed by the Sarbanes-Oxley Act, SOA, in July 2002, plus the NYSE Corporate Governance Rules, which are coordinated with the SOA, added in November 2003.

${ }^{2}$ Cf. Wymeersch E., Comparative Corporate Governance: Essays and Materials, Oxford, 1997; Roe M.J, Political Determinants of Corporate Governance, 2003.

${ }^{3}$ The main characteristics that are common to all joint-stock companies regard: legal personality, the limited liability of shareholders, the transferability of stocks that is occasionally limited by a small number of shareholders or by limitations on their circulation, the administrative organ responsible for economic management, and the ownership of the company in the hands of investors. The complementary nature of the above characteristics that are shared by most joint-stock companies does not always make them certain, as in the case of "closed companies" that limit the transferability of stocks (envisaged by law, in the case of 'limited liability companies' in Italy, or similar structures in Germany, France and the UK, or even letting autonomous articles limit stock circulation, when this is envisaged by law). The worldwide spread of joint-stock companies explains the need to focus on the clarity and transparency of relations that occasionally underpin opportunistic behaviour and conflicts of interest, such as those between managers and shareholders, between majority and minority shareholders, and between shareholders and some other stakeholders like employees or creditors. Cf. Kraakman R.R., Davies P., Hansmann H., Hertig G., Hopt K. J., Kanda H., Rock E. B., Diritto societario comparato, Il Mulino, Bologna, 2006.

${ }^{4}$ In our opinion, the evolution from a shareholder theory to a stakeholder theory does not exclude but, on the contrary, strengthens the priority, in a composite blend of interests (which should exclude the possibility of acting to the detriment of the employee or of creditors), of pursuing shareholder value as the main objective that is able to guarantee the promotion of aggregate social wellbeing, on the basis of the effectiveness, efficiency and economy of corporate operations.

5 The theoretical effectiveness of the vertical two-tier model compared to the traditional model, which envisages the direct intervention of the shareholders to appoint/dismiss the governance organ and the supervisory organ, must be compared to the delicate hierarchical relationship that is established between the people actually responsible for control (members of the supervisory board) and those subject to the control (members of the management board), because the latter are appointed by the supervisory board. A very difficult situation is created if we consider that in addition to appointing the members of the management board the members of the supervisory board can also dismiss them and determine their remuneration, and that the supervisory board may therefore be required to judge the correctness of operations that it has authorised. In other words, if it is managed badly and not controlled, a response to the need to involve shareholders in the life of the company risks increasing the possibility of corruption and congestion of the governance system. This risk exists, because the subordination of members of the management board to members of the supervisory board cannot guarantee the impartiality and independence of each one that is necessary for the correct functioning of the company. Cf. Cassano R., Società per azioni: confronto tra $i$ modelli di governance, Il Sole24Ore, Informatore Pirola, n. 41, Milan, 2006.

In this regard, intervention by watchdogs designed to establish a clear distinction between the supervisory board and the management board, is currently being debated and formalised. This would prevent the chairman of the supervisory board from taking part in the meetings of the management board, but allow the chairman of the internal audit committee to attend meetings of the management board, indicating the criteria to determine strategic investments and define the role of the management board for appointments in investee companies.

${ }^{6}$ In this regard, it would be advisable to note and assess whether, for example, the independence and autonomy of directors (non-executive directors) and members of committees are useful to avoid 
conflicts of interest and to protect all the social interlocutors, and whether these requirements are only met by imposing standards or whether simple recommendations suffice.

${ }^{7}$ For further analysis we refer you to: Salvioni D.M., "Le politiche di comunicazione delle aziende di credito e le informazioni economiche", in AA.VV., Le comunicazioni nelle banche, Il Sole24Ore, Milan, 1987; Salvioni D.M., Economic Information in global corporate communication process, Economia Aziendale, Vol. IX, n. 2, August 1990; Brondoni S.M., Comunicazione, risorse invisibili e strategia competitiva d'impresa, Sinergie, n. 43-44, May-December, 1997; Salvioni D.M., Comunicazione, cultura e governo d'impresa, Sinergie, n. 43-44, 1997; Brondoni S.M., Ouverture de 'Corporate Culture and Market Complexity', Symphonya. Emerging Issues in Management (symphonya.unimib.it), n. 2, 2002; Mancini D., Quagli A., Marchi L. (edited by), Gli intangibles e la comunicazione d'impresa, Franco Angeli, Milan, 2003.

${ }^{8}$ For further analysis we refer you to Almici A., "La comunicazione economico-finanziaria ed i vincoli normativi”, in D. M. Salvioni, C. Teodori (edited by), Internet e comunicazione economicofinanziaria d'impresa, Franco Angeli, Milan, 2003.

${ }^{9}$ We point out that in this work we will compare the two common law countries (United States and United Kingdom) with Europe (primarily Italy, France, Germany).

${ }^{10}$ For example, the Conseil National de la Comptabilité, the Comité Professionel de Doctrine Comptable, the Commission des Operations de Borse and the Ordre des Experts Comptables in France, or the WirtschaftsprüferKammer in Germany, and the Ordine dei Dottori Commercialisti e dei Ragionieri Commercialisti in Italy.

${ }^{11}$ Companies are considered global when they gradually step up their relations and trade in all parts of the world and tend to take on economic, technical-commercial and cultural aspects that are differentiated but complementary.

${ }^{12}$ Management control is classified as a management tool that is able to sum up and standardise governance orientation of decisions and the implementation of intervention strategies linked to operations in different countries.

${ }^{13}$ Where means of communication are concerned, this refers on one hand to the presence of links, updates, disclaimers etc. and, on the other, to the quantity and quality of compulsory and voluntary economic-financial and governance information.

${ }^{14}$ The idea of homogeneous company refers to the abandon of standardised and uniform models from a strategic, organisational and managerial viewpoint in favour of unique entrepreneurial decisions and success that are difficult to replicate in the short term. Cf. Rebora G., Global Markets, Leadership and Public Governance, Symphonya. Emerging Issues in Management (symphonya.unimib.it), n. 1, 2004.

15 The context described refers, in particular, to the need to spread a global culture based on principles of equity, correctness, transparency and truthfulness in international markets, creating different and contrasting interests linked to governance choices and internal and external management activities. Cf. Salvioni D. M., Corporate Governance, Management Control and Global Competition, Symphonya. Emerging Issues in Management (symphonya.unimib.it), n. 1, 2005.

16 These are:

- European alliances that have used Network strategies - a model of the relationship between Stock Exchanges that outlines a collaboration agreement involving each company-market in a federative project (e.g. Euronext); or investment strategies - an integration model that refers to ownership structures and leads to a merger between companies-markets (e.g. Eurex);

- worldwide alliances, with plans for collaboration between European and non-European stock exchanges (e.g. Globext) and the discussed merger between the Italian Stock Exchange and the London Stock Exchange. 